\title{
КЛИНИКО-МОРФОЛОГИЧЕСКИЕ ОСОБЕННОСТИ ЗУБОЧЕЛЮСТНОЙ СИСТЕМЫ У ДЕТЕЙ С ГИПОФИЗАРНЫМ НАНИЗМОМ
}

${ }^{1}$ Туаева М.С., ${ }^{1,2}$ ДиановО.А., ${ }^{1}$ Ульяновская С.А., ${ }^{2}$ Дубровская Е.С.

${ }^{1}$ ФББОУ ВО «Тверской государственный медицинский университет» Минздрава России, Тверь, Россия

${ }^{2}$ ГБУЗ Тверской области «Клиническая детская больница №2»,

Тверь, Россия

Цель: определить клинико-морфологические особенности зубочелюстной системы у детей с гипофизарным нанизмом.

Материал и методы: проведено обследование 35 пациентов с гипофизарным нанизмом в возрасте от 8 до 17 лет, наблюдающихся в Эндокринологическом центре ГБУЗ Тверской области «КДБ №2». Помимо клинико-анамнестического метода применялся биометрический метод, включающий в себя изучение диагностических моделей челюстей. Проводился анализ развития зубов, сроков их прорезывания, наличия скученности, выявление аномалии формы и положения зубов. Данные обработаны методами непараметрической статистики.

Результаты: При изучении состояния зубочелюстной системы у пациентов с гипофизарным нанизмом отмечалось: скученность зубов встречалась в 90\% случаев, поздняя смена зубов - в 70\%, наличие дистального прикуса - в 60\%, глубокий прикус - в 40\%, прямой прикус наблюдался у $30 \%$ обследуемых, ортогнатический прикус - у 20\% пациентов после ортодонтического лечения. Выявлялись аномалии положения зубов: наличие одного центрального резца на верхней челюсти, эктопическое прорезывание зубов, наличие трем и диастем, транслокация зубов, тортоаномалии, протрузия резцов на верхней и нижней челюстях, вестибулярное положение верхних клыков; аномалии формы зубных рядов: V- образный зубной ряд. При проведении анализа диагностических моделей по методу Пона-Линдера-Харта отмечалось сужение зубных дуг в трансверзальном направлении на верхних и нижних челюстях.

Выводы: у детей с гипофизарным нанизмом присутствует ряд особенностей челюстно-лицевой области: снижение высоты нижней трети лица, позднее прорезывание зубов, уменьшение размеров челюстей, скученность зубов, высокая частота встречаемости дистального прикуса, что требует ортодонтической реабилитации. 